\title{
STAG2 wt Allele
}

National Cancer Institute

\section{Source}

National Cancer Institute. STAG2 wt Allele. NCI Thesaurus. Code C101347.

Human STAG2 wild-type allele is located in the vicinity of Xq25 and is approximately 462 $\mathrm{kb}$ in length. This allele, which encodes cohesin subunit SA-2, plays a role in sister chromatid adhesion. 